\title{
EVALUASI PENERAPAN MODEL PEMBELAJARAN E-LEARNING PADA PELATIHAN DASAR CALON PEGAWAI NEGERI SIPIL
}

\section{EVALUATION OF E-LEARNING MODELS IMPLEMENTATION IN BASIC TRAINING OF PROSPECTIVE CIVIL SERVANTS}

\author{
Muhammad Abdi Rahman, Rustan Amarullah, dan Kemal Hidayah \\ Pusat Pelatihan dan Pengembangan dan Kajian Desentralisasi dan \\ Otonomi Daerah Lembaga Administrasi Negara \\ JL. H. M. Ardans (Ring Road III) samarinda, Kalimantan timur \\ Email: abdi.kukar@yahoo.co.id; rustanamarullah8@gmail.com; \\ hidayahkemall@gmail.com
}

Naskah diterima: 2 Maret 2020; revisi terakhir: 14 April 2020; disetujui: 21 April 2020

How to Cite: Rahman, Muhammad Abdi., Amarullah, Rustan., dan Hidayah, Kemal. (2020). Evaluasi Penerapan Model Pembelajaran E-Learning pada Pelatihan Dasar Calon Pegawai Negeri Sipil. Jurnal Borneo Administrator, 16 (1), 101-116. https://doi.org/10.24258/jba.v16i1.656

\begin{abstract}
Technological developments in the industrial 4.0 revolution era have driven changes in the ways of work and use of resources in the digital era. Likewise, training mechanism, from conventional learning patterns to the network learning (online). Training and development in the government environment has discussed aggressively the concept of e-learning to provide new learning alternatives for trainees. This research used a qualitative-descriptive tried to evaluate the effectiveness of e-learning model in the Basic Training of Prospective Civil Servants. The results showed that the implementation of e-learning was effective enough to be used to increase participants' understanding of the training subjects. The quality and sustainability of the use of $e$ learning need to be improved so that it can effectively complement classical learning (blended learning). Mapping of efforts to optimize e-learning has also been identified starting from revamping the e-learning system/ application, learning facilitators, implementation time, and the need to adapt conventional learning elements.
\end{abstract}

Keywords: E-learning, Training, Basic Training, Prospective Civil Servants (CPNS)

\begin{abstract}
Abstrak
Kemajuan teknologi di era revolusi industri 4.0 telah mendorong terjadinya perubahanperubahan cara kerja dan penggunaan sumber daya ke arah digital. Begitu juga mekanisme pelatihan, dari pola pembelajaran konvensional secara klasikal ke pembelajaran dalam jaringan (daring). Pelatihan dan pengembangan di lingkungan pemerintahan sudah mulai gencar mengadopsi konsep pembelajaran e-learning guna memberikan alternatif pembelajaran baru bagi peserta pelatihan. Penelitian ini secara
\end{abstract}


kualitatif-deskriptif mencoba mengevaluasi efektivitas penerapan model pembelajaran secara e-learning pada lingkup Pelatihan Dasar Calon Pegawai Negeri Sipil. Hasil studi ini mengindikasikan bahwa implementasi e-learning cukup efektif digunakan untuk meningkatkan pemahaman peserta terhadap mata pelatihan. Kualitas dan keberlangsungan penggunaan e-learning perlu ditingkatkan sehingga dapat secara efektif melengkapi pembelajaran klasikal (blended learning). Pemetaan terhadap upaya mengoptimalkan e-learning juga telah diidentifikasi mulai dari pembenahan sistem/aplikasi e-learning, fasilitator pembelajaran, waktu pelaksanaan, dan perlunya adaptasi unsur-unsur pembelajaran konvensional.

Kata kunci: E-learning, Pelatihan, Pelatihan Dasar, CPNS

\section{A. PENDAHULUAN}

Pengembangan kompetensi bagi Aparatur Sipil Negara (ASN) tidak lagi dipandang sebagai sebuah pilihan tetapi sudah menjadi sebuah hak yang bisa dituntut pemenuhannya oleh ASN kepada organisasi. Hal ini sesuai dengan Undang-Undang Nomor 5 Tahun 2014 Tentang Aparatur Sipil Negara, pasal 21 yang menyebutkan bahwa salah satu hak ASN adalah mendapatkan pengembangan kompetensi. Dasar ini tentu memberikan bentuk pemahaman bahwa pengembangan ASN menjadi komponen yang sangat penting untuk mendapatkan perhatian yang besar bagi semua pihak yang terkait. Saat ini kondisi ASN yang dinilai memiliki kompetensi rendah masih cukup besar, yaitu setidaknya $45 \%$ dari keseluruhan jumlah ASN (LAN, 2018). Untuk itu, Lembaga Administrasi Negara (LAN) sebagai lembaga yang diamanahi untuk melakukan pembinaan atas pelatihan dan pengembangan aparatur telah menerbitkan Peraturan LAN Nomor 10 Tahun 2018 tentang Pengembangan Kompetensi ASN yang diharapkan dapat menjadi pedoman dalam penyelenggaraan peningkatan kompetensi aparatur. Selain itu, pelaksanaan penyelenggaraan pelatihan aparatur juga sudah mengalami perubahan kurikulum dan proses penyelenggaraan yang disesuaikan dengan tuntutan dan kondisi serta isu yang berkembang saat ini.

Saat ini kecepatan perkembangan teknologi sungguh sangat pesat dan tidak dapat dihindari. Pertumbuhan dan kecanggihan teknologi telah mengubah banyak hal dalam tatanan kehidupan sosial di masyarakat. Kemudahan, kecepatan, dan kenyamanan yang diberikan melalui pemanfaatan teknologi dan informasi membuat teknologi tidak lagi sebuah pilihan, melainkan sudah merupakan sebuah kebutuhan. ASN yang mampu beradaptasi dengan memanfaatkan teknologi terkini, eksistensinya akan tetap terjaga. Saat ini produkproduk inovasi yang berkembang dengan pemanfaatan teknologi dan informasi sudah sangat banyak dan mudah sekali untuk ditemukan, baik yang digunakan di sektor privat maupun publik.

Kemajuan teknologi, khususnya di dunia digital sudah dimanfaatkan hampir di setiap sektor kehidupan manusia. Pemanfaatan teknologi telah terbukti memberikan nilai tambah yang signifikan pada kemajuan cara kerja ataupun produk yang dihasikan pada sebuah organisasi. Sektor pendidikan misalnya, terbukti mampu memanfaatkan kemajuan teknologi dan perkembangannya dengan cukup cepat. Terbukti dengan menjamurnya perkuliahan online, atau seminar dan diskusi online yang kesemuanya memberikan kemudahan dalam proses pembelajaran dan diseminasi pengetahuan. Dalam masyarakat modern, teknologi $e$ learning tersebut adalah model pendidikan yang semakin populer (Yanuschik, Pakhomova, \& Batbold, 2015:154). Pemanfaatan teknologi berbasis e-learning ini juga telah memberikan inspirasi pada dunia pelatihan aparatur di tengah upaya mencari alternatif atau teknik baru dalam mengembangkan kompetensi yang dimiliki oleh aparatur. Saat ini e-learning sudah 
mulai diterapkan di berbagai pelatihan aparatur karena dianggap dapat mengefisiensikan anggaran yang digunakan dalam sebuah pelatihan.

Metode $e$-learning merupakan metode yang dibutuhkan dalam mengadaptasi kemajuan era digital melalui pemanfaatan dukungan kecanggihan teknologi informasi. Tidak dapat dihindari segala hal saat ini sudah berbasis digital, baik konten maupun mekanisme (Elyas, 2018:1). Secara filosofis Gani (2016:19) menyatakan bahwa pembelajaran elektronik (elearning) dapat dipahami sebagai: komunikasi, pengutaraan informasi, pelatihan dan pendidikan dalam jaringan (daring); penyediaan sekumpulan komponen alat untuk memperluas pengalaman, wawasan, dan nilai belajar sebelumnya (secara konvensional dalam kelas) sehingga mampu menghadapi tantangan perkembangan global; serta pembelajaran secara online bukan berarti mengambil alih bentuk dan cara pembelajaran di dalam kelas secara konvensional, namun justru menguatkan mekanisme belajar tersebut dengan improvisasi content serta peningkatan pemanfaatan teknologi pelatihan.

Hartanto (2016:14-15) menjelaskan bahwa keberhasilan e-learning dikarenakan adanya interaksi optimal antara peserta pelatihan dan berbagai fasilitas pelatihan, antara peserta pelatihan dan peserta pelatihan lainnya, dan adanya model pembelajaran aktif dalam hubungan tersebut, dan antara peserta pelatihan dan pengajar. Melalui perspektif kemajuan teknologi dan informasi, tersedia kesempatan untuk melakukan pembaharuan total pada rancangan-rancangan pendidikan dan pelatihan yang diselenggarakan selama ini. Corak kemajuan Information and Communication Technologies (ICT) yang ekonomis, efisien, serta terbuka telah melenyapkan batasan atau sekat ruang, tempat, dan waktu yang selama ini terjadi dalam lingkup bidang pendidikan dan pelatihan. Sejumlah pengaruh rasional yang timbul diantaranya meliputi (1) Para peserta pelatihan mampu secara cepat dan mudah mempelajari seluruh komponen substansi pembelajaran di mana pun dan kapan pun tanpa perlu terganggu oleh batasan waktu dan tempat; (2) Para peserta pelatihan memungkinkan untuk berdiskusi dan belajar kepada para pakar, praktisi, dan ahli pada bidang yang menjadi minatnya dengan sangat mudah; (3) komponen dan substansi pendidikan atau pelatihan bahkan dapat bersumber atau diperoleh dari berbagai belahan dunia tanpa batasan ruang dan tempat belajar peserta pendidikan. Meskipun demikian, untuk memanfaatkan peluang tersebut diperlukan beberapa kesiapan utama baik dari sisi pembiayaan, ketersediaan sarana dan prasarana teknologi informasi, kesiapan masyarakat, serta regulasi yang mendorong keberlangsungan penggunaan dan penerapan e-learning.

Rahayu (2010:180) menyebutkan bahwa e-learning memberikan kemudahan peserta pelatihan untuk menuntut ilmu tanpa perlu hadir di kelas secara fisik. Peserta pelatihan dapat berdomisili di mana pun, sedangkan "instruktur" serta pendidikan yang dijalani berlokasi di suatu tempat, suatu kota, atau bahkan di belahan negara lain. Hubungan pembelajaran dapat diselenggarakan melalui metode dalam jaringan yang diakses secara real-time serta on-line ataupun dilaksanakan secara off-line maupun archieved. Peserta menimba ilmu menggunakan laptop atau PC di rumah ataupun di kantor melalui pemanfaatan koneksi jaringan lokal atau dengan koneksi jaringan internet. Peserta pelatihan atau pendidikan juga dapat mengelola secara mandiri waktu untuk belajar, dan pilihan tempat yang memudahkan ia mengakses materi pelatihan.

Saat ini pembahasan e-learning pada kegiatan pelatihan dan pengembangan di dunia pemerintahan (khusus bagi aparatur pemerintah) masih terbatas kajian, jika dibandingkan penelitian terkait e-learning di dunia pendidikan seperti sekolah dan perguruan tinggi yang sudah cukup banyak dilaksanakan. Penelitian e-learning di dunia pemerintahan pernah dibahas oleh Pamugar, Winarno, \& Najib (2014:15) yang menyebutkan bahwa penerapan teknologi informasi dan komunikasi melalui model e-learning pada lingkup pemerintahan 
memiliki corak kekhususan yang cukup berbeda jika dibandingkan dengan lingkup pendidikan tinggi. Perbedaan tersebut berhubungan dengan identitas dan karakter organisasi, mekanisme tata-kerja organisasi, budaya kerja organisasi serta juga kepribadian atau atribut penyelenggara organisasi yang tidak identik antara spektrum pemerintah dengan spektrum perguruan tinggi. Aktivitas pemerintah di bidang pelatihan dan pengembangan dikhususkan dalam rangka meng-upgrade kapabilitas dan keunggulan para aparatur organisasinya dalam mendorong kinerja organisasi yang lebih optimal. Manifestasi aktivitas tersebut diwujudkan dalam bentuk penyelenggaraan pelatihan dan pengembangan (latbang) atau bimbingan teknis (bimtek) bagi para aparatur pemerintah, yang beberapa pola pelaksanaannya menerapkan metode e-learning. Kelemahannya adalah proses pendidikan dan pelatihan di organisasi pemerintah terbatas diselenggarakan hanya saat latbang/ bimtek dan tidak dapat dijalankan setiap saat. Dengan demikian, interaksi penggunaan pembelajaran online (daring) sangat bergantung khususnya pada kesadaran dan minat penyelenggara organisasi dalam memanfaatkan e-learning secara terus-menerus atau berkelanjutan di luar cakupan penyelenggaraan latbang/ bimtek.

Berdasarkan hal tersebut, kajian terkait evaluasi penerapan e-learning pada Pelatihan Dasar Calon Pegawai Negeri Sipil (Latsar CPNS) yang dilaksanakan oleh Pusat Pelatihan dan Pengembangan dan Kajian Desentralisasi dan Otonomi Daerah-Lembaga Administrasi Negara (Puslatbang KDOD) perlu dilakukan, sehingga dapat dijadikan sebagai bahan penyusunan model e-learning yang lebih optimal dalam memberikan pemahaman dan peningkatan kompetensi CPNS. Secara khusus, penelitian ini hendak menjawab pertanyaan penelitian: Bagaimanakah gambaran penerapan pembelajaran e-learning pada Latsar CPNS yang dilaksanakan oleh Puslatbang KDOD?. Penelitian ini merupakan yang pertama dilakukan pada Latsar CPNS Tahun 2020 pola baru sehingga hasilnya juga dapat dimanfaatkan sebagai bahan pertimbangan dan masukan untuk pengambilan kebijakan dalam penyempurnaan penerapan e-learning pada pelatihan CPNS di masa yang akan datang.

\section{B. METODE PENELITIAN}

Studi ini merupakan penelitian deskriptif-kualitatif yang secara khusus diperuntukkan untuk menggambarkan persepsi peserta Latsar CPNS terkait penerapan model pembelajaran melalui e-learning atau online learning pada mata pelatihan Akuntabilitas PNS; Nasionalisme; Etika Publik; Komitmen Mutu; dan Anti Korupsi. Setiap mata pelatihan tersebut disajikan secara e-learning sebanyak tiga jam pelajaran (JP) dan dipandu oleh fasilitator. Fasilitator dalam penelitian ini adalah widyaiswara pengampu mata pelatihan tersebut. Penyajian pembelajaran secara e-learning ini adalah pertama kali dilaksanakan di Latsar CPNS.

Sesuai dengan ketentuan dalam Peraturan Lembaga Administrasi Negara Nomor 12 Tahun 2018 Tentang Pelatihan Dasar Calon Pegawai Negeri Sipil, pasal 6 disebutkan bahwa Pelatihan Dasar CPNS dapat diselenggarakan dalam format pelatihan konvensional/ di kelas dan pelatihan nonklasikal. Adapun pelatihan nonklasikal merupakan mekanisme pembelajaran yang dijalankan paling kurang melalui e-learning.

Responden penelitian ini adalah seluruh peserta Latsar CPNS Angkatan 8 dan Angkatan 9 Tahun 2020 yang diselenggarakan oleh Pusat Pelatihan dan Pengembangan dan Kajian Desentralisasi dan Otonomi Daerah (Puslatbang KDOD). Adapun jumlah responden penelitian ini berjumlah 80 orang yang berasal dari berbagai instansi di lingkungan Pemerintah Kota Balikpapan sebanyak 72 orang, dan dari Universitas Mulawarman sebanyak 8 orang. 
Adapun data dan informasi yang dihimpun dari responden penelitian ini adalah opini atau pendapat tiap-tiap responden terkait efektivitas penerapan $e$-learning dalam menunjang pembelajaran dan peningkatan kapasitas peserta Latsar CPNS. Selanjutnya, analisis terhadap pendapat peserta Latsar CPNS kemudian ditabulasi dan disajikan secara deskriptif melalui grafik distribusi frekuensi.

\section{KERANGKA TEORI}

\section{Pelatihan Bagi ASN}

Merujuk pada pengembangan kompetensi Aparatur Sipil Negara (ASN) sebanyak 20 jam pelajaran per tahun sesuai dengan Undang-Undang No. 5 tahun 2014 tentang Aparatur Sipil Negara dan Peraturan Kepala LAN No. 10 Tahun 2018 tentang Pengembangan Kompetensi ASN, tidak dapat dibebankan secara utuh pada organisasi semata, namun juga merupakan tanggung jawab atasan langsung dan pegawai yang bersangkutan. Bahkan atasan langsung berperan besar pada pengembangan pegawai yang menjadi subordinatnya. Kewajiban pengembangan pegawai dengan terbatasnya pembiayaan pengembangan menyebabkan setiap pimpinan harus mampu untuk meningkatkan keunggulan bawahannya melalui berbagai macam cara. Para Aparatur Sipil Negara mempunyai keistimewaan untuk memperoleh upaya peningkatan kompetensi, akan tetapi masih sering ditemukan aparatur yang sudah cukup lama mengabdi sebagai PNS namun belum pernah mendapatkan pengembangan kompetensi (selain mengikuti pelatihan prajabatan saja). Pengembangan kompetensi dalam bentuk pelatihan dan pengembangan bertujuan untuk merespon tuntutan kinerja individu dan juga organisasi.

Aguinis dan Kraiger (2009:451-474) mendefinisikan pelatihan sebagai upaya terstruktur guna mencapai peningkatan knowledge, skill, dan attitude dalam rangka memajukan efektivitas individu, organisasi, dan tim. Tidak selalu melalui pelatihan saja, tetapi dapat melalui cara dan metode pengembangan kompetensi lainnya. Selain itu, terdapat berbagai macam bentuk pengembangan kompetensi, di antaranya seperti bentuk pelatihan non klasikal lainnya, belajar mandiri, bimbingan di tempat kerja, dan magang. Rancangan pelatihan dan pendidikan yang efektif guna melengkapi kebutuhan organisasi dilandaskan pada hasil analisis kebutuhan, evaluasi pelatihan, desain, dan cara penyampaian. Kewajiban, responsibilitas, dan konsekuensi pekerjaan tidak sama satu dengan yang lain sehingga menjadi cerminan adanya perbedaan antarindividu. Atas dasar hal ini, setiap aparatur memerlukan jenis atau pola pelatihan yang berbeda. Oleh karenanya, pelatihan dan pengembangan dilaksanakan dengan mengacu pada kesesuaian perhitungan diagnosis kebutuhan organisasi dan juga berdasarkan kapasitas/potensi yang dimiliki seorang aparatur, sehingga pelatihan dan pengembangan mampu mempererat serta memperkaya keterampilan serta pengetahuan aparatur tersebut.

Diantara berbagai macam jenis strategi pengembangan pegawai salah satunya dilaksanakan dengan pendekatan program pendidikan dan pelatihan. Smith (2000:2) berpendapat bahwa "training is a planned process to modify attitude, knowledge, skill behavior through learning experience to achieve effective performance in activity or range of activities". Pelatihan didefinisikan sebagai upaya sistematis dan terencana guna memperbaharui pengetahuan, sikap/ perilaku, serta kemahiran melalui proses pengalaman belajar dalam rangka menggapai prestasi yang optimal pada sebuah kegiatan atau sejumlah kegiatan. Pelatihan dikhususkan untuk mendorong peningkatan keterampilan pegawai, baik secara vertical maupun horizontal. Secara horizontal adalah memperkaya keterampilan jenis pekerjaan yang diketahui, sedangkan vertical memperdalam suatu bidang tertentu. 
Khan (2011:63-69) mengemukakan bahwa dalam pelatihan terdapat sejumlah parameter, yakni Instruktur, mempertimbangkan bahwa fasilitator cenderung untuk berfokus kepada peningkatan skill, maka para fasilitator yang ditetapkan untuk menyampaikan materi pembelajaran betul-betul memiliki kualifikasi yang dipersyaratkan sesuai bidangnya, profesional, dan kapabel. Disamping itu, kualifikasi pendidikan fasilitator pun sebaiknya sungguh-sungguh baik untuk melaksanakan pelatihan. Selanjutnya adalah peserta yang mengikuti pelatihan diharapkan memiliki motivasi dan semangat yang tinggi untuk mengikuti pelatihan dan tentunya perlu disaring dengan mengacu pada persyaratan tertentu dan kualifikasi yang sesuai dengan jenis pelatihan.

Materi, dalam pelatihan dan pengembangan pegawai, substansi materi atau kurikulum harus sesuai dengan target pelatihan dan pengembangan pegawai yang ingin dicapai oleh organisasi, dan materi pelatihan dan pengembangan pun sebaiknya sesuai konteks kekinian agar peserta dapat memahami masalah yang terjadi pada situasi dan kondisi saat ini. Metode, metode pelatihan apabila sesuai dengan jenis dan komponen peserta pelatihan akan memberikan jaminan berlangsungnya kegiatan pelatihan sumber daya manusia yang efektif. Tujuan, tujuan pelatihan dan pengembangan perlu ditegaskan, terutama yang terpaut dengan pembuatan rencana aksi (action play) dan penetapan sasaran, serta result yang ingin dicapai dari pelatihan yang dilaksanakan. Selain itu, tujuan pelatihan harus disosialisasikan sebelumnya pada peserta agar peserta dapat memahami pelatihan tersebut. Sasaran, sasaran pelatihan sebaiknya ditetapkan kriterianya secara terinci dan terukur.

\section{E-Learning dan Blended Learning}

Menurut Dahiya et al. (2012:132-135) e-learning merupakan penggunaan teknologi informasi dan komunikasi untuk mendorong keaktifan peserta dapat belajar kapan pun dan dimana pun. Berbagai istilah digunakan untuk pembelajaran elektronik, antara lain onlinelearning, internet-enabled learning, virtual learning, atau web-based learning. Hartanto (2016:5) menyebutkan terdapat tiga persyaratan utama proses pembelajaran secara elektronik (e-learning), yakni (a) aktivitas belajar-mengajar diselenggarakan dengan memanfaatkan jaringan, dalam konteks ini dibatasi pada penggunaan internet, (b) kesiapan dukungan layanan tutor yang mampu membantu peserta pembelajaran ketika menghadapi hambatan atau kesulitan, dan (c) terdapatnya dukungan layanan belajar yang dapat digunakan oleh peserta pembelajaran. Selain ketiga persyaratan tersebut di atas, dapat pula dilengkapi dengan komponen persyaratan lainnya, seperti adanya (a) organisasi yang mengelola dan melaksanakan kegiatan e-learning, (b) motivasi positif dari peserta pelatihan dan tenaga pengajar terhadap pemanfaatan teknologi komputer dan internet, (c) kerangka proses dan sistem pembelajaran yang secara sederhana dapat dipelajari dan diketahui oleh setiap peserta pembelajaran, (d) mekanisme evaluasi terhadap peningkatan atau perkembangan peserta pembelajaran, dan (e) proses pemberian feed-back yang dikembangkan oleh organisasi penyelenggara pembelajaran.

E-learning mempunyai ciri-ciri, antara lain, 1) memiliki konten yang relevan dengan tujuan pembelajaran; 2) menggunakan metode instruksional, misalnya penyajian contoh dan latihan untuk meningkatkan pembelajaran; 3) menggunakan elemen-elemen media, seperti kata-kata dan gambar-gambar untuk menyampaikan materi pembelajaran; 4) memungkinkan pembelajaran langsung berpusat pada pengajar (synchronous e-learning) atau didesain untuk pembelajaran mandiri (asynchronous e-learning); 5) membangun pemahaman dan keterampilan yang terkait dengan tujuan pembelajaran, baik secara perseorangan maupun meningkatkan kinerja pembelajaran kelompok (Clark \& Mayer 2008: 10: 1). 
Pada dasarnya, e-learning dibagi menjadi dua tipe, yaitu synchronous dan asynchronous. Synchronous merupakan pada waktu yang sama. Mekanisme belajarmengajar ini berlangsung pada saat yang sama antara fasilitator dan peserta didik. Hal ini memungkinkan adanya interaksi langsung antara fasilitator dan peserta pelatihan secara online. Pada proses pelaksanaannya, synchronous training mewajibkan fasilitator dan para peserta pelatihan mengakses internet pada waku bersamaan. Fasilitator menyampaikan materi pembelajaran dalam format makalah atau slide presentasi kemudian peserta pelatihan dapat mendengarkan presentasi tersebut secara langsung melalui jaringan internet. Peserta pelatihan juga memiliki kesempatan mengajukan pertanyaan atau opini secara langsung ataupun melalui fasilitas chat window (Hartanto, 2016:5).

Asynchronous diartikan dengan tidak dalam waktu bersamaan. Peserta pelatihan leluasa menentukan waktu pembelajaran yang berbeda dengan fasilitator yang memberikan materi. Asynchronous training populer dalam e-learning sebab peserta pelatihan dapat mengakses materi pembelajaran dimana pun dan kapan pun. Peserta pelatihan dapat mengikuti pembelajaran dan menyelesaikannya setiap saat sesuai rentang jadwal yang telah ditentukan sebelumnya. Pembelajaran juga dapat berbentuk bacaan, animasi, simulasi, permainan edukatif, tes, quiz, dan pengumpulan tugas (Hartanto, 2016:5).

Model pembelajaran campuran atau blended adalah suatu model pembelajaran yang menggabungkan metode pengajaran face to face dengan metode pengajaran berbasis komputer, baik secara offline maupun online untuk membentuk suatu pendekatan pembelajaran yang terintegrasi (Idris, 2011:62). Sebelumnya, materi-materi berbasis digital telah dipraktikkan, tetapi dalam batas perannya sebagai penopang atau penunjang, yaitu untuk mendukung pengajaran face to face. Tujuan dari blended learning adalah untuk memberikan pengalaman pembelajaran yang paling efektif dan efisien. Adapun unsur-Unsur pembelajaran berbasis blended learning mengkombinasikan antara tatap muka dan $e$ learning yang memiliki enam unsur, yaitu (a) tatap muka (b) aplikasi, (c) belajar mandiri, (d) tutorial, (e) kerjasama, dan (f) evaluasi (Amin, 2017:58).

Keuntungan yang diperoleh dengan diterapkannya pembelajaran berbasis blended bagi lembaga pendidikan atau pelatihan adalah, memperluas jangkauan pembelajaran serta pelatihan; kemudahan penerapan; efisiensi biaya; hasil yang optimal; menyesuaikan berbagai kebutuhan pembelajaran; dan meningkatkan daya tarik pembelajaran (Idris, 2011:68). Keistimewaan penggunaan e-learning dan juga blended learning dalam pelatihan saat ini adalah e-learning menyediakan fleksibilitas dalam memilih tempat dan waktu untuk mengakses materi pembelajaran, sehingga tidak perlu mengadakan perjalanan menuju tempat pelajaran disampaikan. E-learning dapat dilakukan dari mana saja baik yang memiliki akses ke internet maupun tidak. E-learning memberikan keleluasaan bagi ASN secara mandiri memegang kendali atas keberhasilan pelatihan. Peserta pelatihan dapat menentukan kapan akan mulai, kapan akan menyelesaikan, dan bagian mana dalam satu modul yang ingin dipelajarinya terlebih dahulu. Seandainya, setelah diulang masih ada hal yang belum ia pahami, peserta dapat menghubungi fasilitator atau narasumber melalui email, chat atau ikut dialog interaktif pada waktu-waktu tertentu.

\section{HASIL DAN PEMBAHASAN}

Dalam Latsar CPNS, implementasi metode pembelajaran secara e-learning dilaksanakan pada mata pelatihan Akuntabilitas PNS, Nasionalisme, Etika Publik, Komitmen Mutu, dan Anti Korupsi. Kelima mata pelatihan tersebut diselenggarakan secara blended, yakni secara klasikal, tiap mata pelatihan sebanyak 9 JP dan $e$-learning sebanyak 3 JP untuk setiap mata pelatihan tersebut. Pembelajaran e-learning dapat diakses kapan saja 
untuk melihat atau men-download modul, video, dan bahan tayang (Asynchronous). Khusus untuk synchronous atau diskusi online bersama fasilitator (live chat) dilakukan secara terjadwal. Adapun alamat website untuk mengakses pembelajaran e-learning adalah www.dev-elearning.lan.go.id.

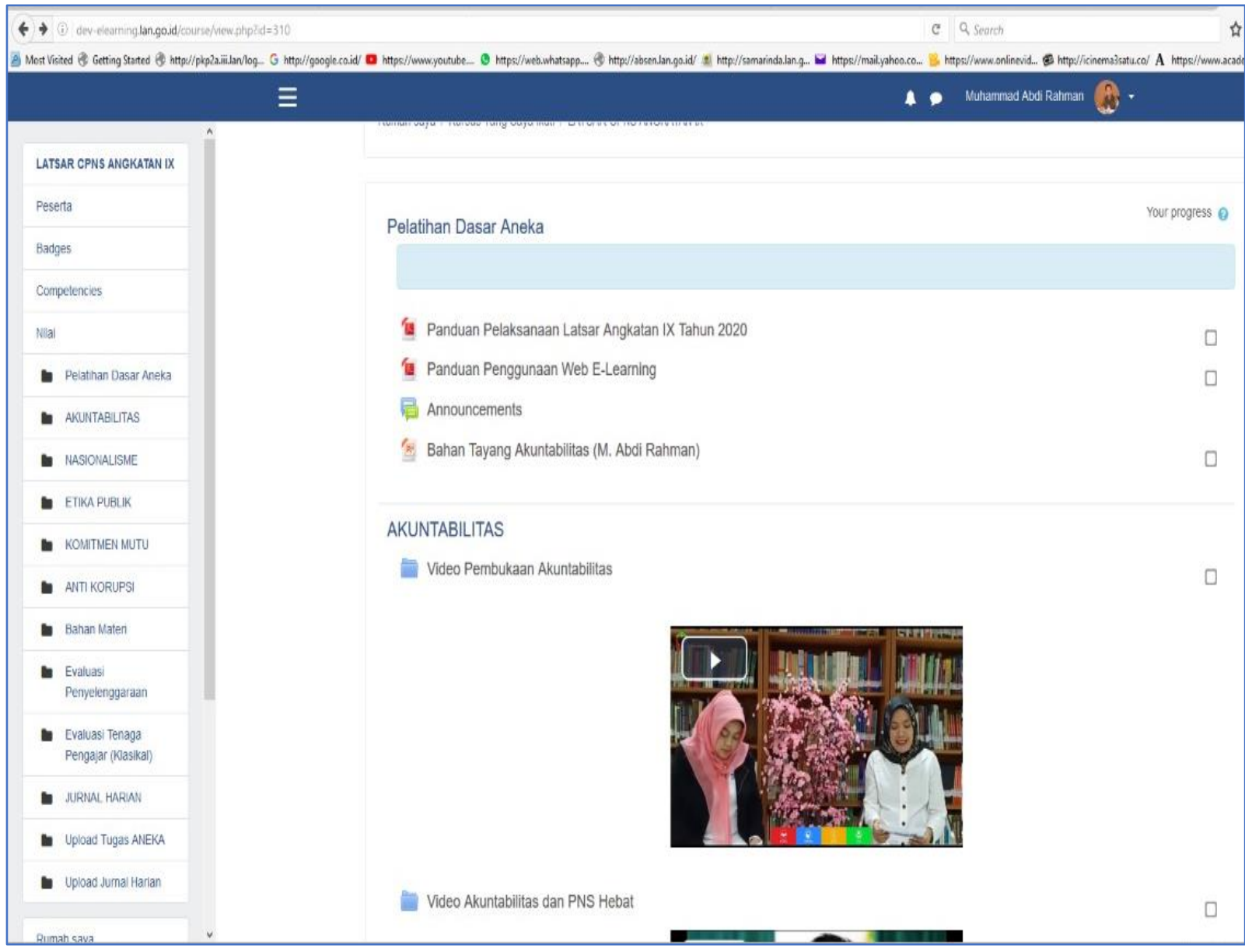

Gambar 1.

Tampilan website e-learning Latsar CPNS Tahun 2020

Peserta Latsar CPNS Angkatan 8 dan Angkatan 9 tahun 2020 didominasi oleh perempuan, yaitu sebanyak 58 orang $(72,5 \%)$ dan laki-laki sebanyak 22 orang $(27,5 \%)$. Persebaran pendidikan menunjukkan tingkat kompetensi yang cukup tinggi dari para peserta latsar CPNS, yakni Sarjana (S-1) sebanyak 75 orang dan pendidikan Master (S-2) sebanyak 5 orang. Jika ditinjau dari persebaran usia, peserta latsar CPNS masih berada pada rentang usia muda, yakni yang berumur antara 20-30 tahun sebanyak 56 orang atau sekitar $70 \%$, dan rentang 30 - 40 tahun berjumlah 24 orang atau 30\%. Penerapan e-learning dengan generasi muda atau generasi milenial akan sangat memudahkan dalam pengimplementasiannya karena mereka saat ini cukup dekat dan mengenal trend penggunaan teknologi, menyenangi tantangan dan hal baru, cepat beradaptasi pada aplikasi, serta penggunaan internet secara intensif. 


\section{Persepsi Peserta Terhadap Penerapan E-Learning}

Agar e-learning dapat berjalan optimal, kemudahan penggunaan atau operasionalisasi pembelajaran secara daring tersebut menjadi penting untuk dianalisis. Semakin mudah menggunakan komponen atau fitur yang tersedia, akan semakin memperlancar proses transfer of knowledge suatu mata pelatihan. Selain itu, kemudahan dan kelancaran akses website e-learning juga menjadi hal utama yang perlu dipersiapkan sehingga fleksibilitas pembelajaran dapat dengan mudah dilaksanakan di waktu kapan pun dan dari mana saja.

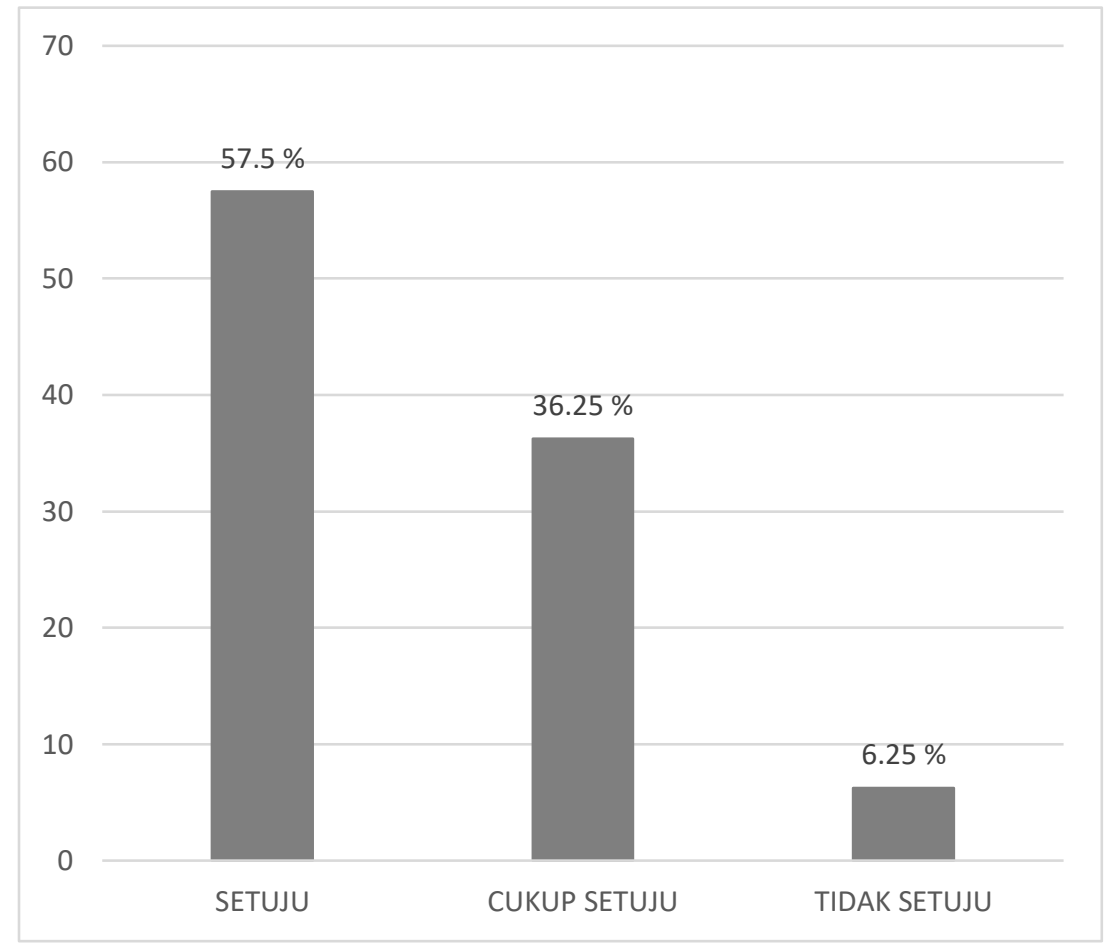

Gambar 2.

Persepsi Peserta Latsar CPNS Terhadap Tampilan dan Kemudahan Mengoperasikan $E$ Learning

Terhadap kemudahan pengoperasian e-learning, 46 orang atau 57,5\% memberikan respons mudah digunakan dan 29 orang atau 36,25\% mengatakan cukup mudah digunakan (Gambar 2). Kemudahan ini disebabkan oleh adanya petunjuk operasional penggunaan $e$ learning yang tersedia pada website e-learning tersebut, sehingga disebutkan sebagai hal yang memudahkan penggunaan seluruh fitur pembelajaran $e$-learning.

Kemudahan pengoperasian beragam menu dalam e-learning juga didukung oleh tingkat penguasaan aplikasi dan penggunaan internet para peserta yang seluruhnya merupakan generasi milenial. Para generasi milenial tentu tidak asing dengan beragam aplikasi baik yang berbasis website ataupun berbasis smartphone, seperti aplikasi e-learning tersebut (www.dev-elearning.lan.go.id.). Mereka relatif telah mampu secara mandiri menjelajahi semua unsur menu-menu pelatihan yang tersedia, sehingga dapat secara langsung mengakses dan mengoperasikannya. Bahkan dapat membandingkan kemampuan aplikasi e-learning ini dengan aplikasi-aplikasi lain yang sudah ada sebelumnya. Hal ini terlihat dari saran peserta Latsar CPNS tersebut yang mengatakan bahwa aplikasi e-learning saat ini memiliki beberapa kekurangan pada fitur yang tersedia, seperti tidak tersedianya pilihan penyertaan video, emoticon, suara, serta tampilan live chat sangat kecil, juga reply chat dan riwayat chat yang kurang mendukung. 
Proses pembelajaran secara e-learning merupakan salah satu variasi pembelajaran yang baru pertama kali diterapkan pada latsar CPNS. Melalui website e-learning tersebut, para peserta dapat melihat modul seluruh mata pelatihan serta bahan tayangnya. Kesan peserta terhadap pembelajaran secara e-learning direspons oleh 31 orang atau 38,75\% yang berpendapat e-learning cukup nyaman dibandingkan klasikal, bahkan 28 orang atau $35 \%$ berpendapat lebih nyaman dalam e-learning (Gambar 3). Hal ini disebabkan pembelajaran e-learning dapat dilaksanakan di mana pun dan kapan saja (fleksibel) sehingga tidak monoton seperti pembelajaran klasikal. Mereka dapat mengatur jadwal secara praktis untuk mempelajari lebih awal terhadap seluruh agenda pelatihan yang akan dijalani. E-learning memberikan kelonggaran bagi peserta pelatihan untuk mengontrol secara mandiri kesuksesan dan kelancaran belajar masing-masing, artinya peserta pelatihan memiliki keleluasaan untuk memutuskan waktu untuk memulai dan akan menyelesaikannya, serta bagian atau tahapan mana dalam materi pelatihan yang hendak dipelajarinya terlebih dulu. Jika menghadapi hambatan dan kendala, peserta dapat dengan mudah mengulang-ulang sampai memahami substansi pelatihan (Hartanto, 2016:8).

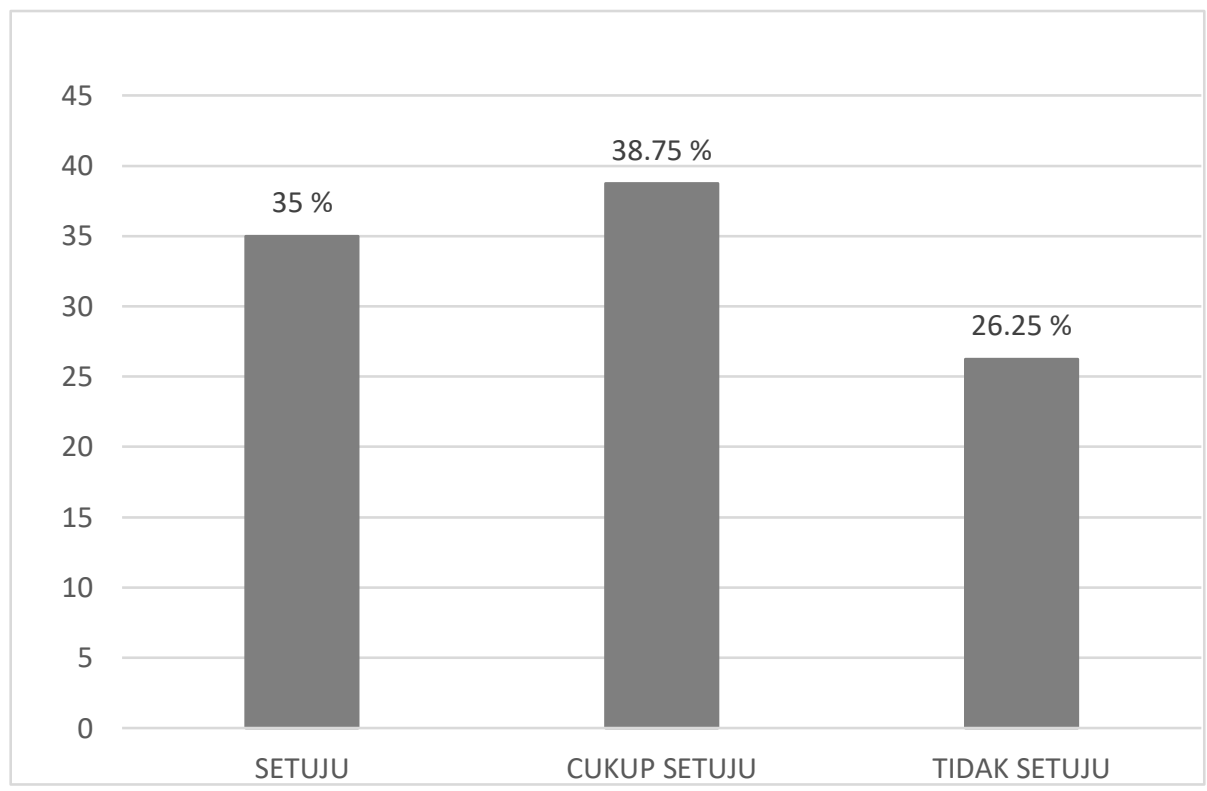

Gambar 3

Persepsi Peserta Latsar CPNS Terhadap Kenyamanan Pembelajaran Melalui ELearning Dibandingkan Pembelajaran di Kelas (Classical)

Para peserta juga lebih leluasa dalam penyampaikan pendapat dan pertanyaan pada sesi live chat yang terjadwal khusus bersama dengan para fasilitator pengampu mata pelatihan tersebut. Pendalaman atas materi yang disampaikan dapat diulas pada sesi diskusi online tersebut, sehingga melalui pola ini akan memacu peserta untuk memahami materi dan mendiskusikan hal yang belum dipahami secara langsung.

Hasil senada disampaikan dalam penelitian Sukamto (2012:75) yang menyebutkan durasi dan periode yang tersedia bagi pendidik dan peserta untuk bertemu langsung di ruang kelas sangat terbatas. Di sisi yang lain, mekanisme delivery bahan ajar hampir sepenuhnya diselenggarakan dalam ruang kelas yang berakibat penyampaikan bahan ajar dapat terlambat atau bahkan tidak tersampaikan jika pertemuan di kelas tidak terjadi. Situasi tersebut menyebabkan perkembangan peserta pelatihan menjadi terhambat. Untuk mengatasi persoalan tersebut, diperlukan model pembelajaran e-learning. 
Hal berbeda disampaikan oleh 21 orang peserta lainnya atau sekitar 26,25\% yang menyebutkan bahwa pembelajaran di kelas lebih baik dibandingkan pembelajaran e-learning. Mereka berargumen bahwa di kelas diskusi lebih efektif dan mendalam dibandingkan $e$ learning. Mereka dapat berinteraksi langsung dengan fasilitator dan peserta lainnya, juga dapat dipantau apakah peserta sudah paham atau tidak dengan materi yang diberikan. Selain itu, e-learning cenderung membuat fokus pembelajaran kurang optimal karena harus melihat monitor secara terus-menerus, berbeda dengan klasikal yang fasilitator dapat memberikan ice-breaking yang seru dan menyenangkan untuk tetap meningkatkan semangat belajar peserta. Pemahaman materi lebih lengkap dan mendalam karena mendapatkan penjelasan langsung, dibandingkan e-learning yang penyampaian materi kebanyakan masih dalam bentuk teks saja. Meski demikian, secara keseluruhan peserta menyampaikan bahwa $e$ learning merupakan opsi pelengkap selain pembelajaran di kelas. Hal ini sesuai penelitian Silahuddin (2015:57) yang mengatakan e-learning belum dapat mengambil alih peran dan keuntungan dari metode pembelajaran klasikal (konvensional). Hal ini disebabkan karena metode serta desain pembelajaran yang diterapkan dalam proses e-learning belum dapat mengimbangi superioritas metode interaksi langsung tatap muka secara konvensional. Akibatnya, hingga kondisi saat ini, e-learning dengan berbagai keunggulannya lebih sesuai berperan sebagai pelengkap, penunjang, atau penyokong bagi metode pembelajaran konvensional atau klasikal, terutama dalam pelatihan.

Dari hasil ini terlihat bahwa e-learning berperan cukup efektif sebagai penyampaian awal materi pembelajaran atau dapat dikatakan sebagai persiapan pembelajaran. Selain itu, juga penting sebagai upaya me-review ulang materi, sedangkan pendalaman materi lebih optimal disampaikan di kelas karena dapat lebih leluasa secara detail mendengarkan pemaparan fasilitator. Hal ini sesuai dengan pendapat Elyas (2018: 2) yang mengatakan bahwa memadukan antara interaksi secara tatap muka dengan metode pembelajaran via online dapat mendorong peningkatan kontribusi dan interaktifitas antarpeserta pelatihan. Melalui klasikal atau tatap muka peserta pelatihan dapat mengenal sesama peserta pelatihan dan instrukturnya. Keakraban ini sangat menunjang kerjasama dan kolaborasi mereka secara virtual.

Diskusi dalam pembelajaran e-learning dilakukan antara peserta dan fasilitator pengampu mata pelatihan dan proses diskusi telah ditetapkan secara terjadwal. Dalam pelaksanaannya, 44 orang atau 55\% mengatakan cukup efektif, bahkan 15 peserta atau $18,75 \%$ menyebutkan proses diskusi melalui e-learning sudah efektif (Gambar 4). Hal ini didasari pada kemudahan dalam penyampaian pertanyaan secara langsung dan cepat. Para peserta dapat menyusun pertanyaan dan langsung klik "Send" tanpa perlu menunggu giliran atau kesempatan bertanya terlebih dahulu seperti di kelas. Selain itu, para peserta juga dapat melihat/membaca pertanyaan-pertanyaan yang disampaikan oleh peserta lainnya. Para peserta juga terlihat berani mengutarakan pertanyaan atau mengeluarkan pendapat, dan semua bisa memantau. Pertanyaan tersebut langsung mendapatkan tanggapan dari fasilitator serta dapat ditanggapi oleh peserta lainnya. Jawaban-jawaban fasilitator juga dianggap cukup baik karena mudah dipahami, jelas, dan memberikan memberikan konsep dan contoh nyata dari setiap pertanyaan yang diajukan. 


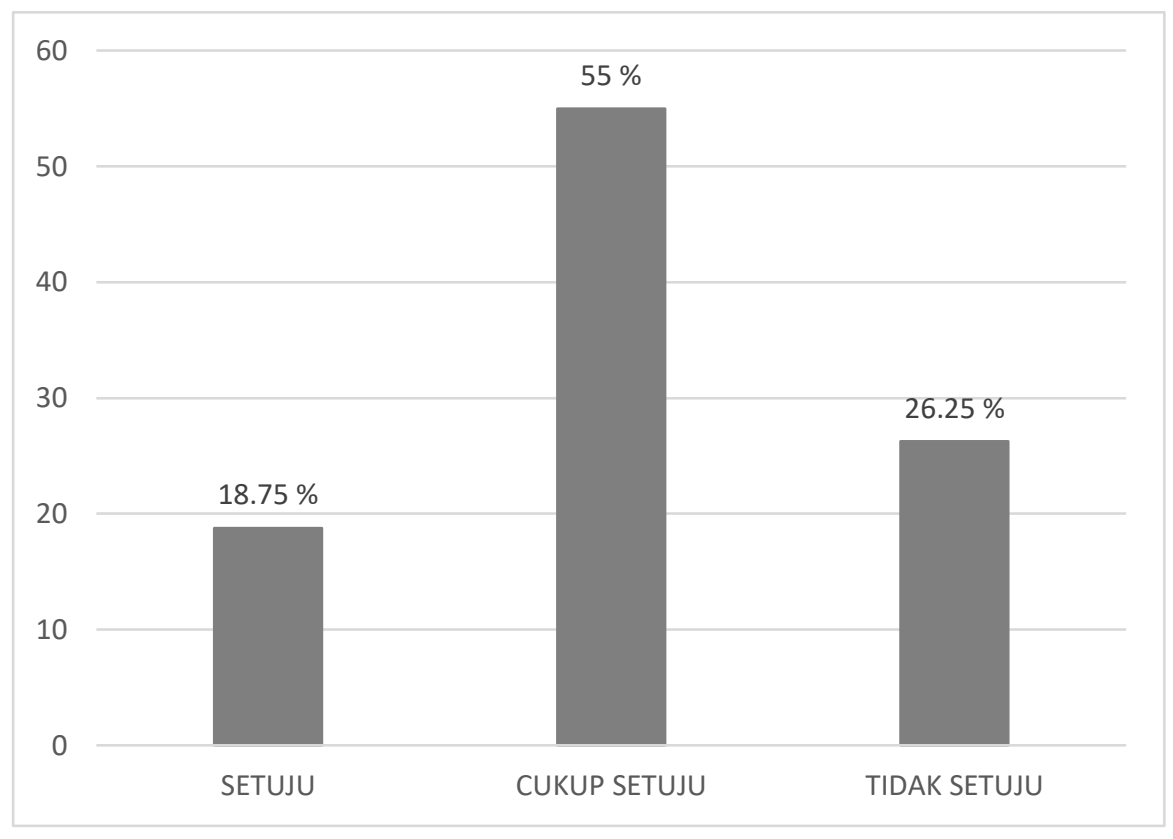

Gambar 4.

Persepsi Peserta Latsar CPNS Terhadap Efektivitas Proses Diskusi yang Dilakukan Melalui E-Learning

Meskipun demikian, 21 orang atau 26,25\% menganggap diskusi dalam e-learning berjalan kurang efektif. Hal ini disebabkan oleh fitur chat untuk diskusi memiliki kelemahan yang membutuhkan pengembangan ke depannya. Dalam chat diskusi sering kali "saling menumpuk" karena banyaknya peserta yang memberikan pertanyaan atau menanggapi, sehingga peserta merasa kurang dapat fokus membaca diskusi yang berlangsung, bahkan banyak pertanyaan yang terkadang terlewat untuk dibahas. Selain itu, tidak terdapat fitur reply langsung (seperti pada aplikasi whatsapp) sehingga peserta tidak dapat langsung menanggapi pada pointer pertanyaan atau tanggapan tertentu.

Oleh karena itu, dianggap perlu ada moderator yang mengatur jalannya diskusi agar lebih optimal, atau minimal perlu ada aturan terkait diskusi di e-learning agar lebih terstruktur. Hal lain yang dianggap kurang efektif adalah keterbatasan ruang live chat, sehingga penjelasan yang terlalu panjang, baik dari peserta maupun fasilitator kurang mampu dibaca dengan efektif (harus menggeser atau naik turun).

Keaktifan peserta di dalam diskusi $e$-learning juga tidak dapat terlihat, karena peserta bisa saja tidak menyimak diskusi atau tidak aktif (pasif). Berbeda ketika diskusi secara langsung di kelas yang dianggap lebih fokus, terkoordinasi dengan baik, dan dapat saling mendengarkan tanggapan masing-masing. Selain itu, fasilitator dapat mengoptimalkan keaktifan peserta selama proses diskusi berlangsung sehingga semua peserta dapat terlibat.

Seperti disampaikan sebelumnya, proses diskusi telah ditetapkan secara terjadwal sehingga terdapat batasan waktu dalam proses diskusi online (live chat), yakni selama 3JP (pukul 16.00-18.15 Wita). Namun demikian, dari waktu 3 JP tersebut, 34 orang atau 42,5\% menganggap sudah cukup panjang, dan $38,75 \%$ atau 31 orang berpendapat sudah sesuai. Dengan demikian, dapat disimpulkan bahwa waktu diskusi secara daring tidak terlalu singkat dan relatif sudah efektif. Namun, beberapa peserta mengungkapkan agar jam pelaksanaan diskusi dalam e-learning masih perlu disesuaikan atau disepakati bersama agar para peserta tidak terburu-buru dan tidak mengganggu aktivitas peserta yang lainnya (sholat, makan, dll). 
Atas dasar persepsi peserta Latsar CPNS Tahun 2020 tersebut dapat disimpulkan bahwa pemanfaatan e-learning sebagai salah satu metode pembelajaran pada mata pelatihan Akuntabilitas PNS, Nasionalisme, Etika Publik, Komitmen Mutu, dan Anti Korupsi berjalan efektif dan berlangsung sesuai dengan tujuan yang diharapkan. Proses pembelajaran peserta secara asynchronous dan synchronous dapat berjalan optimal. Meskipun demikian, diperlukan pembenahan pada beberapa fitur e-learning yang tersedia dan mekanisme penyesuaian penjadwalan synchronous. Kualitas dan keberlangsungan penggunaan $e$ learning perlu senantiasa dijaga dan ditingkatkan sehingga tujuan pembelajaran tetap tercapai. Hasil penelitian Suharyanto dan Mailangkay (2016:20) menemukan bahwa $e$ learning berpengaruh positif dan signifikan terhadap mutu pembelajaran.

Selanjutnya, perlu dipetakan beberapa upaya untuk mengoptimalkan pemanfaatan $e$ learning sebagai salah satu metode pembelajaran yang efektif pada Latsar CPNS. Kualitas dan keberlangsungan penggunaan e-learning tentu perlu ditingkatkan sehingga dapat secara efektif melengkapi pembelajaran klasikal. Atas dasar pemetaan ini, penyelenggara pelatihan dapat menganalisis terobosan pembenahan atau tindak lanjut terhadap permasalahan yang ada.

Pertama, terkait sistem e-learning, perlu disiapkan jaringan internet atau infrastruktur lain yang mendukung kelancaran akses terhadap bahan-bahan pembelajaran e-learning secara langsung kapan pun dan di mana pun. Aplikasi yang tersedia membutuhkan pengembangan khususnya pada menu diskusi (keleluasaan ruang diskusi, fitur reply langsung, dll). Selain itu, juga dapat ditambahkan fitur pengiriman icon, gambar, audio, dan lain-lain, sehingga proses diskusi menjadi lebih hidup. Variasi konten pembelajaran $e$ learning juga perlu diperbanyak seperti quiz, simulasi, praktek, dan lain-lain.

Guna mampu menyediakan e-learning yang menarik dan diminati serta dalam rangka memajukan kualitas pembelajaran, terdapat tiga elemen yang wajib dipenuhi dalam merancang e-learning, yaitu (1) Sederhana, sistem yang simple akan memudahkan peserta pelatihan dalam menggunakan teknologi, aplikasi, dan menu yang tersedia. Kemudahan penggunaan pada panel-dashboard yang disediakan, waktu belajar peserta akan lebih efisien; (2) Personal, pengajar/ fasilitator dapat berinteraksi dengan baik dengan peserta pelatihan seperti lazimnya berkomunikasi di depan kelas. Dengan pendekatan dan interaksi yang lebih personal, peserta pelatihan dipantau kemajuannya, juga dapat dibantu segala hambatan atau kendala yang dihadapi; dan (3) Cepat, layanan yang didukung dengan tingkat kecepatan yang tinggi, respons yang cepat dalam menangani keluhan dan kebutuhan peserta pelatihan, sehingga penyempurnaan pembelajaran dapat dilakukan sesegera mungkin oleh fasilitator atau pengelola pelatihan (Elyas, 2018:8).

Kedua, terkait fasilitator pembelajaran, perlu terus melakukan pengembangan kompetensi khususnya pada upaya menyiapkan bahan tayang dan video yang lebih menarik, serta kemampuan dalam menjawab pertanyaan dan memberikan tanggapan yang mudah dipahami oleh peserta. Dengan media yang menarik dan sesuai dengan kebutuhan peserta pelatihan, diharapkan peserta pelatihan dapat lebih mudah memahami materi pembelajaran dan tidak mudah bosan (Rodiawati dan Komaruddin, 2018:184). Melalui penggunaan $e$ learning, peserta pelatihan tidak hanya pasif mendengarkan uraian materi dari pendidik saja, tetapi juga aktif mengamati, melakukan, mendemonstrasikan, dan lain-lain sebagainya. Materi bahan ajar dapat ditransformasikan ke dalam berbagai bentuk atau format sehingga lebih menarik dan lebih dinamis, serta mampu memotivasi peserta pelatihan untuk lebih jauh mendalami dalam proses pembelajaran (Hartanto, 2016:3). 
Ketiga, terkait waktu pelaksanaan e-learning, fleksibilitas waktu untuk diskusi dalam jaringan perlu disesuaikan atau disepakati waktu pelaksanaannya secara bersama-sama dengan peserta. Dengan demikian, keaktifan seluruh proses diskusi dapat berjalan optimal.

Selain ketiga hal di atas, optimalisasi e-learning dapat dilakukan dengan mereplikasi unsur-unsur yang biasa dijalankan dalam sistem pembelajaran klasikal/ konvensional, misalnya dimulai dari perumusan tujuan yang operasional dan dapat diukur, ada apersepsi atau pre-test, membangkitkan motivasi, menggunakan bahasa yang komunikatif dan sederhana, uraian materi yang jelas, contoh-contoh konkrit, problem solving, tanya jawab, diskusi, post-test, hingga penugasan dan kegiatan tindak lanjutnya. Oleh karena itu, dalam merancang e-learning juga perlu melibatkan berbagai pihak terkait, antara lain: pengajar, ahli materi, ahli komunikasi, programmer, dan seniman (Silahuddin, 2015:56).

Blended learning merupakan solusi alternatif untuk menanggulangi kelemahankelemahan pembelajaran online dan pembelajaran tatap muka dalam rangka menghasilkan rangkaian pembelajaran yang efektif, efisien, dan menyenangkan bagi peserta pelatihan dengan tidak menggeser teori-teori pembelajaran lama. Berbagai riset oleh para peneliti juga menunjukkan bahwa mekanisme pembelajaran blended learning mempunyai pengaruh hasil yang tinggi dibandingkan dengan pembelajaran online atau tatap muka (Abdullah, 2018:864).

\section{E. PENUTUP}

Penelitian ini menyimpulkan bahwa proses pembelajaran secara e-learning sudah cukup efektif dan mampu berperan dalam mendukung proses peningkatan kemampuan peserta dalam memahami beberapa mata pelatihan dalam Latsar CPNS. Akses e-learning lebih awal oleh peserta akan memberikan gambaran atau pengantar suatu mata pelatihan dan memudahkan dalam melakukan review atas materi pelatihan secara optimal. Selain itu, kemudahan dalam berdiskusi secara online antarpeserta dengan fasilitator dengan jangka waktu yang cukup panjang akan semakin efektif memuaskan keingintahuan peserta terhadap suatu persoalan dalam mata pelatihan. Berdasarkan hasil analisis dan pembahasan telah diidentifikasi upaya mengoptimalkan $e$-learning mulai dari pembenahan sistem/aplikasi $e$ learning, fasilitator pembelajaran, dan waktu pelaksanaan, serta perlunya mengadaptasi unsur-unsur pembelajaran konvensional.

Guna melengkapi pendalaman atau perluasan atas materi pelatihan, pembelajaran klasikal memegang peranan penting. Selain itu, pembelajaran klasikal juga menawarkan adanya interaksi antara fasilitator dan peserta secara aktif sehingga penguatan pemahaman pelatihan dapat lebih efektif. Dengan demikian, penggabungan antara metode pembelajaran di kelas (klasikal) dan e-learning secara blended learning menjadi solusi efektif dalam Latsar CPNS.

\section{DAFTAR PUSTAKA}

Abdullah, Walib. (2018). Model Blended Learning dalam Meningkatkan Efektifitas Pembelajaran. Fikrotuna: Jurnal Pendidikan dan Manajemen Islam, 7 (1), 855-866

Aguinis, Herman, \& Kraiger, Kurt. (2009). Benefits of Training and Development for Individuals and Teams, Organizations, and Society. Annual Review of Psychology, 60(1), 451-474. https://doi.org/10.1146/annurev.psych.60.110707.163505

Amin, Ahmad Kholiqul. (2017). Kajian Konseptual Model Pembelajaran Blended Learning berbasis Web untuk Meningkatkan Hasil Belajar dan Motivasi Belajar. Jurnal Pendidikan Edutama. 4 (2), 51-64

Clark, Ruth. Colvin, \& Mayer, Richard. E. (2008). E-learning and The Science of Instruction: Proven Guidelines for Consumers and Designers of Multimedia Learning, Second 
Edition. San Francisco: John Wiley \& Sons, Inc.

Dahiya, Shashi., Jaggi, Semma., Chaturvedi, K. K., Bhardwaj, Anshu., Goyal, R. C., \& Varghese, Cini. (2012). An eLearning System for Agricultural Education. Indian Res. J. Ext. Edu, 12(3), 132-135.

Elyas, Ananda Hadi. (2018). Penggunaan Model Pembelajaran E-Learning Dalam Meningkatkan Kualitas Pembelajaran. Jurnal Warta, Edisi 56, April 2018, 1-11. Universitas Dharmawangsa

Gani, Alcianno G. (2016). E-Learning Sebagai Peran Teknologi Informasi Dalam Modernisasi Pendidikan. Jurnal Sistem Informasi (JSI) Universitas Suryadarma, 3 (1), 1-19. DOI: https://doi.org/10.35968/jsi.v3i1.52

Hartanto, W. (2016). Penggunaan E-Learning sebagai Media Pembelajaran. Jurnal Pendidikan Ekonomi, 10(1), 1-18.

Idris, Husni. (2011). Pembelajaran Model Blended Learning. Jurnal Iqra', 5 (1), 61-73

Khan, Raja Abdul Gafoor., Khan, Furqan Ahmed., \& Khan, Muhammad Aslam. (2011). Impact of Training and Development on Organizational Performance. Global Journal of Management and Business Research, 11(7), 63-69. https://doi.org/10.1017/CBO9781107415324.004

LAN, (2018). Sosialisasi Kebijakan Pengembangan Kompetensi ASN. Retrieved from http://www.lan.go.id/id/berita-lan/sosialisasi-kebijakan-pengembangan-kompetensiasn-2

Pamugar, Haris., Winarno, Wing Wahyu., \& Najib, Warsun. (2014). Model Evaluasi Kesuksesan dan Penerimaan Sistem Informasi E-Learning pada Lembaga Diklat Pemerintah. Scientific Journal of Informatics, 1 (1), 13-28.

Peraturan Kepala LAN No. 10 Tahun 2018 tentang Pengembangan Kompetensi ASN. (2018). Lembaga Administrasi Negara Republik Indonesia.

Rahayu Chandrawati, S. (2010). Pemanfaatan E-Learning dalam Pembelajaran. Jurnal Cakrawala Kependidikan, 8(2), 172-181.

Rodiawati, Heni., dan Komarudin. (2018). Pengembangan E-Learning Melalui Modul Interaktif Berbasis Learning Content Development System. Jurnal Tatsqif: Jurnal Pemikiran dan Penelitian Pendidikan, 172-185.

Silahuddin. (2015). Penerapan E-Learning dalam Inovasi Pendidikan. Jurnal Ilmiah CIRCUIT, 1 (1), 48-59.

Sukamto, Binar Cipta Anggara. (2012). E-Learning Jaringan Komputer Berbasis Web dan $\begin{array}{lllllll}\text { Aplikasi Mobile. Jurnal Teknik Elektro, } 1 & \text { (2), 75-78. } & \text { DOI: }\end{array}$ https://doi.org/10.32497/jtet.v1i2.17

Suharyanto, dan Mailangkay, Adele B. L. (2016). Penerapan E-Learning Sebagai Alat Bantu Mengajar dalam Dunia Pendidikan. Jurnal Ilmiah Widya, 3 (4), 17-21.

Smith, Andrew. (2000). Training and Development In Australia. In Reed International Books Australia Pty Buuterworths. Australia. (Vol. 53). https://doi.org/10.1017/CBO9781107415324.004

Undang-Undang No. 5 tahun 2014 tentang Aparatur Sipil Negara. (2014). Undang-undang Republik Indonesia No.5 tahun 2014 tentang Aparatur Sipil Negara. 1-104.

Yanuschik, Olga V., Pakhomova, Elena G., \& Batbold, Khongorzul. (2015). E-learning As A Way to Improve the Quality of Educational for International Students. Procedia Social and Behavioral Sciences, 215, $147-155$. 
